\title{
Danmark fik en
- med tydelige geo-aftryk
}

naturkanon
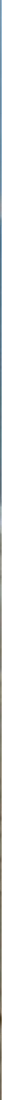

Den danske naturkanon skal inspirere danskere til at laere de navne, der beskriver den danske natur. Sand, klit og klint bør vare lige så velkendte ord som fyrtårn og fodspor. (Foto: Morten L. Hjuler)

Af Tove Damholt og Anette Reenberg

Hvad er det nu med det kanonvæsen - er det ikke et for længst overstået kapitel? Er det overhovedet en god idé? Kan det bruges til noget? Ja, kanontanken har givet anledning til debat og til mange overvejelser, men i 2008 blev det besluttet at igangsætte udarbejdelsen af en dansk naturkanon, og så var det jo op til enhver, om man ville være med eller imod.

Den første kanonfase var en offentlighedsfase, hvor den danske befolkning blev inviteret til at komme med forslag til, hvad Danmarks naturkanon skulle rumme. Rigtigt mange tog imod opfordringen, og $i$ alt indkom der mere end 1.400 forslag, som blev samlet ind ved arrangementer fordelt i hele landet, via debatfora, pr. mail eller pr. SMS. Forslagene dannede baggrund for naturkanonens anden fase, hvor et kanonudvalg blev nedsat med det formål at lave lister. Udvalget, der var udpeget af miljøministeren, bestod af 12 faglige eksperter, 5 borgere, som repræsenterede den almin- delige naturbruger og derudover et medlem udpeget af undervisningsministeriet.

\section{Hvad er en kanon?}

En kanon er normalt en udpegning af det vigtigste og fineste, og sådan var det da også med den danske kulturkanon. Men den danske naturkanon er tænkt helt anderledes, og derfor slap udvalget heldigvis for at dømme om en guldsmed er vigtigere og finere end en mariehøne.

I den danske naturkanon er formidlingen det primære. Tanken med naturkanonen er, at den skal hjælpe til at udbrede kendskabet til den danske natur og bidrage til flere naturoplevelser til os alle. Og så skal naturkanonen bruges i undervisningen, $\mathrm{fx}$ i folkeskolen.

Naturkanonudvalget har derfor i udpegningen af de enkelte elementer på listerne lagt vægt på, at de kunne bruges som en øjenåbner for større naturhistorier. Historier, der kan være gode at gribe fat $i$, når man skal formidle den danske natur. Derfor rummer naturkanonen både spektakulær natur og helt almindelig natur, og her er både eksempler på succeshistorier i naturforvaltning og eksempler på det modsatte. Naturkanonen kan på den måde fungere som en øjenåbner for meget større historier. En rhombeporfyr kan fx åbne for historier om vulkaner, pladetektonik, mineraler og gletscherdynamik og istider.

\section{Er geologi natur?}

Udvalgets første opgave var at beslutte, hvor mange lister naturkanonen skulle rumme, og geologiens rolle var ikke givet, men som det fremgår af resultatet, var stemningen for geologi og geografi meget positiv. Vi har ellers næsten vænnet os til, at geologien ofte har en tilbagetrukken rolle i den offentlige formidling og forvaltning af Danmarks natur, hvor den typisk står i skyggen af den biologiske natur. Men ved udarbejdelsen af naturkanonen blev der fundet rigtigt god plads til at pege på de mange geo-værdier.

Ud af de 16 naturkategorier i naturkanon er der blevet plads til både en liste med undergrund, en liste med sten, en med landskabsformer og en med fortidens natur. Ud over disse fire lister er geo-emner også at finde på listen med naturtyper og i høj grad også i listen over steder.

Stederne er den del af naturkanonen, der har fået langt den største opmærksomhed i pressen, hvor mange lokale medier, helt som forventet, fokuserede på deres eget områdes kanon-værdige natur. Og i den forbindelse blev kanonen klart opfattet som noget særligt og bevaringsværdigt, så der er håb for, 
at naturkanonen lokalt kan bruges som et argument for at beskytte naturen i disse udpegede områder.

\section{Hvad nu?}

Den danske naturkanon vises i første omgang på naturkanon-hjemmesiden (www. naturkanon.dk) - hvor man ud over listerne også kan se udvalgets meget korte begrundelser. Men forhåbentlig følger der mere. Kontakten til Undervisningsministeriet er taget, og første trin til udarbejdelse af undervisningsmateriale er taget. Herudover har kanonudvalget anbefalet miljøministeren en række formidlingstiltag herunder en dynamisk hjemmeside, en flot bog, bedre formidling i public service-kanaler og nye midler til formidling. Udmeldingerne var positive, da miljøministeren modtog udvalgets forslag, og hvad der videre vil ske er nu helt op til miljøministeren.

Som smagsprøver kan man nedenfor læse udpluk fra de mest geo-relevante kanon-kategorier: sten, undergrund, landskabsformer, fortidens natur og naturtyper - og fra kategorien "steder", som i sig selv er en kilde til naturhistorier om samspil mellem landskabets dynamik, biologien og geologien.

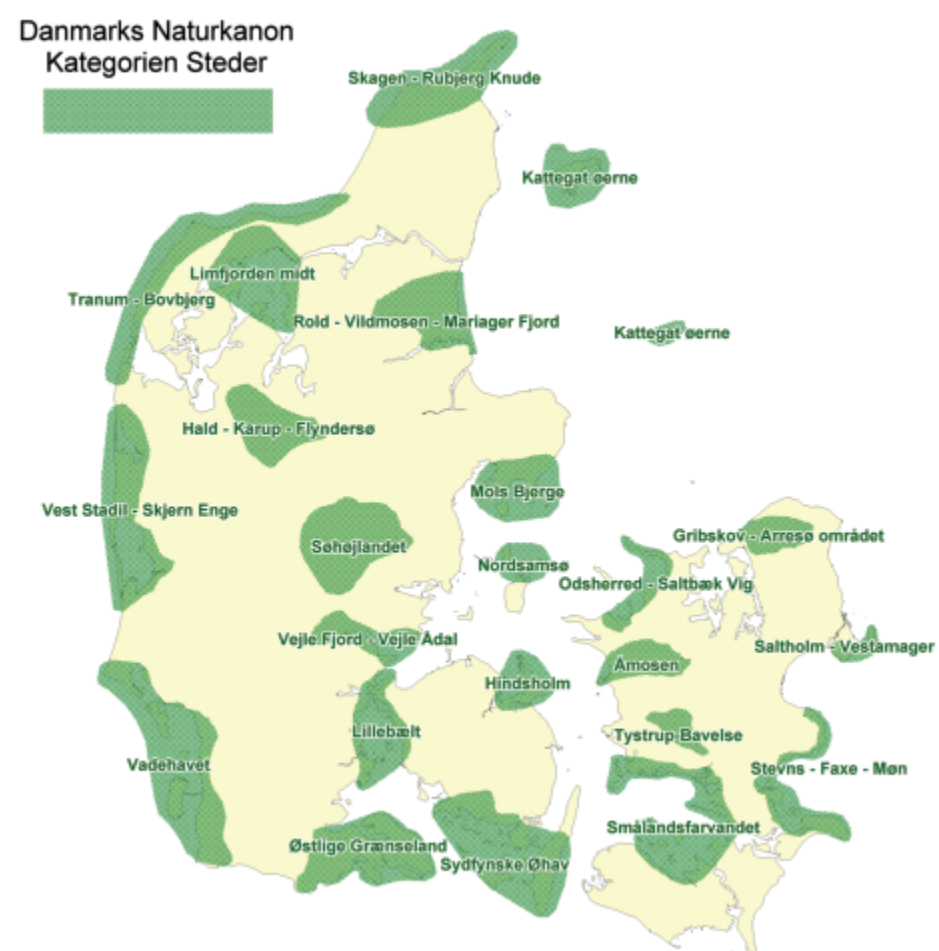

I alt 24 naturområder i Danmark er udpeget i naturkanonen. Her kan man opleve kanonelementerne fra de mange andre lister med pattedyr, insekter, sten osv. Stederne dcekker også mange danske naturperler, og netop udpegningen af steder vakte stor lokal opmarksomhed ved offentliggørelsen. (Grafik: Skov-og Naturstyrelsen)

\section{Landskabsformer}

Det danske landskab er formet af istidens gletschere og smeltevand og afrundet af det hav, som skyllede ind over landet, da isen smeltede bort. Spredt rundt i landet danner havets bølger og luftens vinde i dag stadig nye landskabsformer.

\section{Moræneflade}

Morænefladen, der er den dominerende landskabsform i store dele af Danmark, er skabt nede under en gletscher. Når gletscheren glider hen over et område, kan den både erodere og afsætte materiale (moræneler), og herved modellerer den landskabet. Moræneflader kan både være pandekageflade og smukt bølgede.

\section{Randmoræne}

Randmorænen er det tydeligste aftryk fra de gletschere, der har skabt det danske landskab. Gletscheren har lige som en bulldozer skubbet randmorænen op. Randmorænen viser helt præcist, hvor isens rand har stået på et bestemt tidspunkt.

\section{Smeltevandsflade}

Hvor der er is, er der vand. Millioner af kubikmeter af smeltevand er løbet fra gletscheren og har medbragt sten, grus, sand og ler

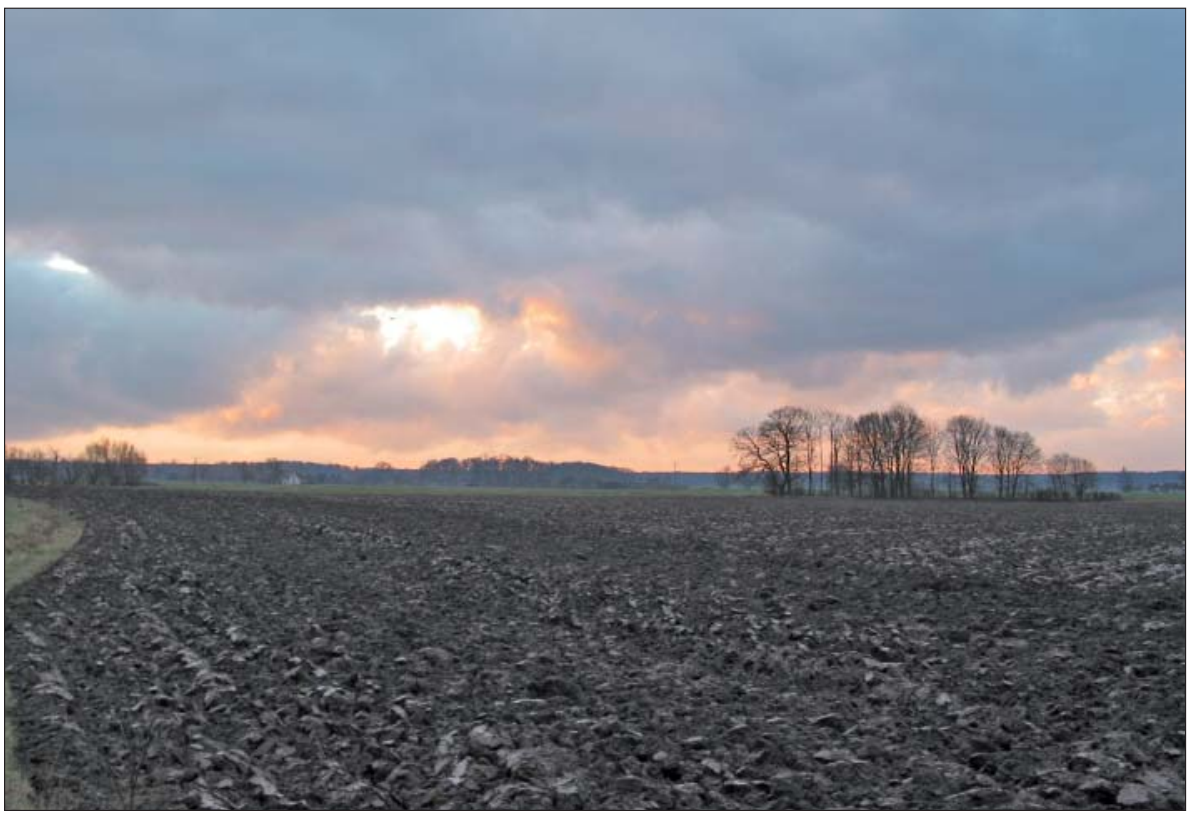

Morcenefladen er så almindelig at et hvert barn bør kende den - og kunne give den et navn. Derfor har den fået en plads i naturkanonen. (Foto: Tove Damholt)

fra isens overflade og indre. De groveste materialer er blevet afsat i smeltevandsfloderne og opbygger smeltevandsfladerne, der er den dominerende landskabsform i Vestjylland, men også findes spredt $\mathrm{i}$ resten af landet.

\section{Bakkeø}

Bakkeøerne i Vestjylland er - bortset fra Bornholms grundfjeldsprægede landskaber - de ældste landskaber i Danmark. De stammer nemlig fra næstsidste istid og ikke fra 
sidste istid, som hovedparten af de danske landskaber. Bakkeøerne indeholder forskellige landskabsformer, fx moræneflader, randmoræner og forskellige dale. På grund af den høje alder er de enkelte former mere afrundede af vejr og vind, end det typisk ses i de yngre landskaber.

\section{Tunneldal}

Tunneldale er markante landskabselementer med en særpræget historie. Tunneldale dannes nemlig, hvor smeltevand løber i tunneller under en gletscher. På grund af isens vægt har vandet højt tryk og kan derfor erodere dybe huller ned i underlaget. Når isen smelter væk, og tunneldalen ligger tilbage, bliver de dybere huller i dalen ofte til søer.

\section{Dødishul}

Dødishuller er spor efter en klump dødis, det vil sige, en stor klump is fra en gletscher, som ikke længere er i bevægelse, men ligger og smelter. Når isen smelter, bliver der frigivet og afsat store mængder materiale, men der hvor den store isklump ligger, bliver der ikke afsat materiale. Når isklumpen til sidst er smeltet væk, er der et afløbsløst dødishul, der hvor den lå. I dag er der en sø eller mose i bunden af mange dødishuller.

\section{Hævet havbund}

Denne meget flade landskabsform er et resultat af, at Ishavet og senere Stenalderhavet $i$ tiden under og efter istidens afslutning skyllede ind over landet. Siden har landet hævet sig, og disse landskaber, der engang var havbund, ligger nu op til 40 meter over havet.

\section{Druknet landskab}

Druknede landskaber er oprindeligt almindelige istidslandskaber med bakker og dale og har ligget sådan, indtil Stenalderhavet skyllede ind og oversvømmede landskaber særligt i landets sydlige dele. I det sydfynske øhav dukker kun bakketoppene op som øer, mens dalene i dag ligger under vandet.

\section{Klinter}

Langs Danmarks lange kystlinie findes mange kystklinter, der giver et kig ind i den danske undergrund. Klinterne bliver dannet af havets bølger, der skyller ind mod landområderne og har gjort det siden, først Ishavet og senere Stenalderhavet skyllede ind over landet. I områder, hvor landet har hævet sig, kan man se gamle, nu tilvoksede kystklinter inde i landet. Nogle steder ligger disse gamle klinter bag en nuværende, aktiv kystklint.

\section{Odder}

Odder er et eksempel på en landskabsform dannet $i$ havet efter afslutningen af sidste istid. Odder skabes af bølgestrømme, der transporterer sand og grus langs med kysten og afsætter det i læ af odden, der dermed vokser. Mange odder er levende landskabselementer, der stadig udvikler sig.

\section{Klitter}

Klitter adskiller sig fra de øvrige landskabselementer ved at være dannet af vinden. Klitterne dannes, når sand transporteres af vinden og aflejres som sanddyner. Mange klitter er helt unge landskabselementer med en alder, der kan måles i århundreder i stedet for årtusinder. De fleste klitter er i dag tæmmet af vegetation, men enkelte er stadig levende og udvikler sig og vandrer.

\section{Marsk}

Marsk dannes i tidevandsområder, hvor salttålende planter vokser på lavtliggende, jævne flader, så sand og mudder bliver fanget mellem planterne på fladen, som derved bliver højere. Når fladen er vokset op over højvandstanden, kan den stadig vokse videre med nyt sand og mudder, når den bliver overskyllet ved særligt høje højvander og stormfloder.
Danmarks dyre- og planteliv har ændret sig igennem Jordens historie som en følge af livets udvikling (evolutionen), klimaændringer og globale katastrofer. Dermed danner danske naturs forhistorie en vigtig baggrund for at forstå den natur, der omgiver os i dag. Vores væsentligste kilde om den fortidige natur er fossiler, dvs. spor og rester af forhistorisk liv. Fossilerne kan man finde i klinter og råstofgrave og i de sten, som ligger på marker og strande.

\section{Ormerør}

De første danske spor af liv er fra orm. Ormene levede i og på bunden af det hav, der for første gang skyllede ind over grundfjeldet, og siden har orm været til stede i bunden af hvert eneste hav, der er skyllet ind over landet. Ormene selv har ikke noget skelet og bliver ikke bevaret som fossiler, men de spor, som ormene lavede i havbunden, kan blive bevaret som aftryk i havbundens sand.
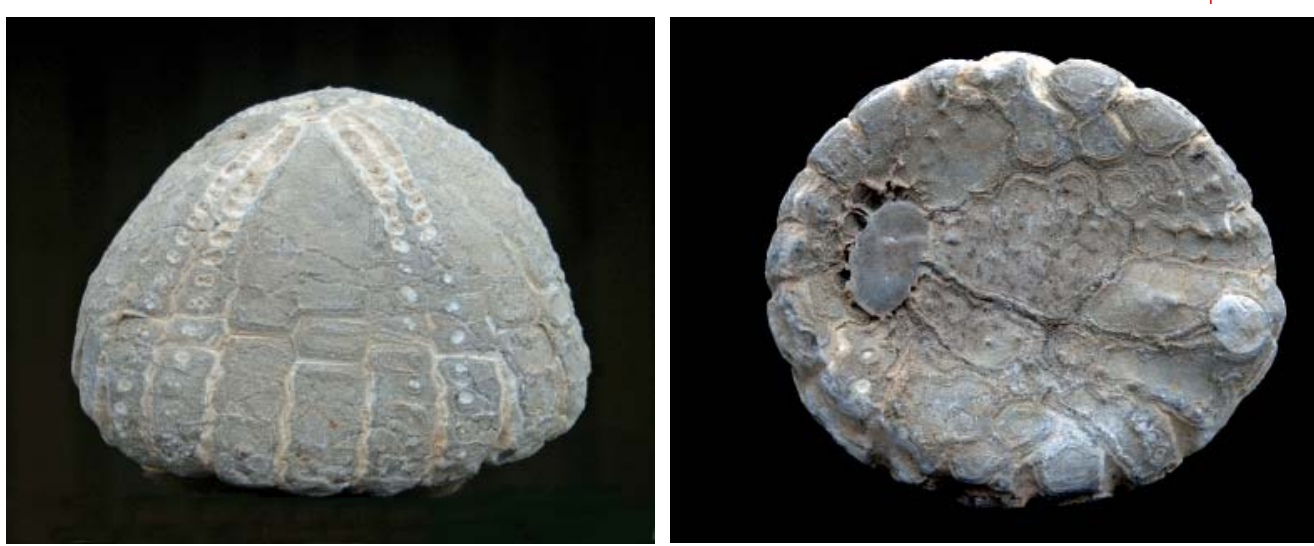

Søpindsvin kan fortcelle gode historier om både naturhistorie og kulturhistorie. Og så er det her et fossil, som mange danskere faktisk kender navnet på. (Fotos: Morten L. Hjuler, 2005)

\section{Trilobit}

Trilobitterne (trilobita) er en repræsentant for det meget tidlige skalbærende liv, der dukkede op i stort antal for ca. 540 millioner år siden i det, der kaldes den kambriske eksplosion. I modsætning til tidligere livsformer har disse organismer skaller og bliver derfor lettere bevaret som fossiler. Trilobitterne uddøde ved Perm/Trias-grænsen for ca. 250 millioner år siden i Jordens værste masseuddøen, hvor mere end $95 \%$ af alle dyrearter uddøde.

\section{Den bornholmske "raptor"}

Denne 140 millioner år gamle dinosaur (Dromaeosauries bornholmensis), som vi kender fra to fossile tænder, kommer fra en gruppe af dinosaurer, som er meget tæt 
beslægtet med fuglene. Tænder er det mest almindelige tegn på, at der har levet dinosaurer i Danmark, og tænder findes i flere forskellige lag på Bornholm. De bornholmske dinosaurer kendes også fra fodspor, der kan fortælle om dyrets liv og adfærd.

\section{Vættelys}

Vættelys er det indre skelet fra en uddød gruppe af blæksprutter. Vættelys-blæksprutterne er repræsentanter for de dyr, der uddøde for 65 millioner år siden i den store masseuddøen, som udslettede over halvdelen af Jordens dyrearter, heriblandt dinosaurerne. Årsagen til den store masseuddøen diskuteres intenst, og da Stevns Klint er et af de mest berømte steder i Verden at studere denne grænse, har Danmark her en nøglerolle. Er kendt fra sagn og overtro.

\section{Søpindsvin}

Søpindsvin er bedst kendt som stenkerner i flint fundet på danske strande, men leder man i de lag af kalk, hvor søpindsvinet stammer fra, vil man støde på søpindsvin $i$ en anden bevaringsform, nemlig som de oprindelige og skrøbelige kalkskaller. Søpindsvin er således ikke bare en repræsentanter for det rige dyreliv i de danske kalkaflejringer, men er også et godt eksempel på forskellige bevaringsformer. Søpindsvin er desuden kendt fra sagn og overtro.

\section{Hajer}

I Danmark kan man finde mange millioner år gamle hajtænder i forskellige lag af ler, kridt eller kalk. Selv om de danske hajtænder er mange millioner år gamle, består de stadig af det oprindelige materiale, og de er stadig lige så skarpe og flænser lige så godt, som dengang hajen tabte dem. Hajens skelet er af brusk og bliver kun yderst sjældent bevaret.

\section{Havskildpadde}

Et af de bedst bevarede danske fossiler findes i moleret, hvor et komplet skelet af en havskildpaddeunge også har bevaret rester af de bløde dele af huden på lufferne og skjoldets hornkant. Det er ekstremt sjældent at finde dette, fordi de bløde dele normalt

Skildpadden "Luffe", der er fundet på Mors, måler 10,5 cm i loengden. Den blev fundet $i 2008$ af Moler Museets leder, Henrik Madsen. (Foto: Henrik Madsen)

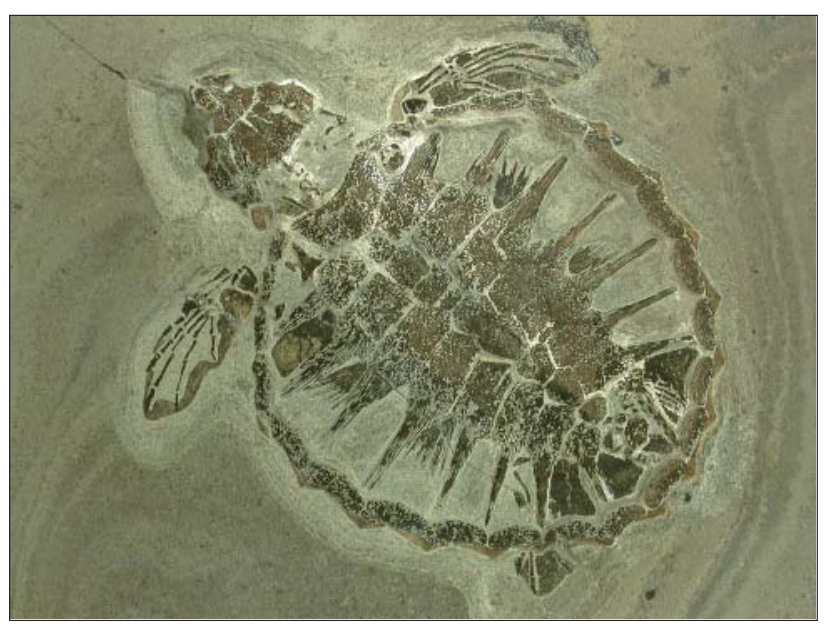

rådner bort. Rester af havskildpadder er fundet $i$ lag af tre forskellige aldre, hvor der i alle tre tilfælde har været et betydeligt varmere klima (subtropisk-tropisk) end i dagens Danmark.

\section{Insekter i moleret}

Selv om de ca. 200 forskellige arter af fossile insekter fra Limfjordsområdet er over 54 millioner år gamle, er de så velbevarede, at man kan se ben, vinger og på nogle af dem endda farvemønstre. Normalt vil døde insekter hurtigt rådne op eller blive spist, men den havbund, insekterne landede på, manglede ilt, og derfor blev de næsten på mirakuløs vis bevaret, og disse fantastiske insektfund er berømte langt ud over Danmarks grænser.

\section{Uldhåret Mammut}

Den uldhårede mammut er valgt som en repræsentant for de store pattedyr, der levede i Danmark under dele af istiderne. Under istiderne var Danmark nemlig i lange perioder isfrit og dækket af vidtstrakte stepper med mammutter og andre store græssende dyr, bl.a. uldhåret næsehorn og steppebison. Mammuttens tænder er robuste og har overlevet, at gletschere senere er gledet hen over området og i de fleste tilfælde splittet de øvrige skeletdele ad.

\section{Rensdyr}

Rensdyret levede i Danmark i de isfri perio- der under sidste istid, og rensdyret var det første større pattedyr, der indvandrede, da landet for sidste gang blev isfrit for 14.500 år siden. Den første forekomst af rensdyr falder sammen med den første optræden af mennesker efter sidste istid (bopladsen ved Slotseng i Sønderjylland), og der er ingen tvivl om, at rensdyret som byttedyr har været forudsætningen for menneskets tidlige tilstedeværelse her i landet.

\section{Urokse}

Uroksen er det største landlevende dyr i Danmark efter sidste istid. Uroksen, som kendes fra mange flotte danske fund, levede her for ca. 11.500-3.000 år siden og var et vigtigt jagtdyr. Den sidste ægte urokse i Verden blev dræbt i Polen i 1627. Uroksen er stamfader til tamoksen og har en vigtig plads i den nordiske mytologi (Audhumla). Urokselignende kvæg bruges i stigende omfang i naturforvaltningen.

\section{Ulv}

Ulven indvandrede allerede kort efter sidste istids afslutning og er det senest uddøde rovdyr i Danmark - den sidste ulv i Danmark blev skudt 1813 ved Estvadgård nær Skive. Ulven har en vigtig rolle i folkekulturen ("store stygge ulv", "ugler i mosen" = "ulve i mosen") og den nordiske mytologi (Fenrisulven). Ulven er stamfader til tamhunden.
Den danske undergrund kan man se i mange små og store kystklinter rundt langs de danske kyster og $\mathrm{i}$ landets mange råstofgrave. Her får man et kig ind i de lag, der gemmer sig under Danmark og fortæller om landets tilblivelse.

\section{Grundfjeld}

Grundfjeldet stikker op på Bornholm, men dybt under resten af Danmark ligger grundfjeldet og danner fundamentet for undergrundens øvrige bjergarter. Grundfjeldet består af bjergarter som granit og gnejs, og er dannet mange kilometer nede i jordskorpen, og adskiller sig derved fra alt andet $\mathrm{i}$ den danske undergrund.

\section{Alun-skifer}

Den sorte alun-skifer, der kan ses langs åer på Bornholm, giver os et kig langt tilbage til det dybe hav, der dækkede Danmark for over 450 millioner år siden, tilbage i en tid før plantelivet var etableret på landjorden. I havet, der dækkede det meste af det nuværende Danmark, levede de for længst uddøde trilobitter og mærkelige graptolitter. På 
havbunden blev der dannet sort slam, som nu er blevet til den alun-skifer, der ligger dybt nede i den danske undergrund.

\section{Salt}

De tykke lag af salt i den danske undergrund kan ikke ses direkte. Saltet blev dannet ved inddampning af et saltholdigt hav i et varmt, tørt ørkenklima for ca. 250 millioner år siden og er siden begravet af andre bjergarter. Da saltet er lettere end andre bjergarter, stiger det op i kæmpestore, pudeformede strukturer eller saltdiapirer og skubber til lagene ovenpå. Kendes særligt fra Nordsøen, Midt- og Nordjylland og former landskabet mellem Thisted og Hanstholm.

\section{Skrivekridt}

Møns Klints høje spir består af skrivekridt skubbet op af sidste istids gletschere for få tusinde år siden. Selve skrivekridtet er med sine mere end 65 millioner år meget ældre end istiderne, og under resten af det danske område ligger det i tykke, vandrette lag, således som det kan ses på Stevns Klint og $\mathrm{i}$ de store kridtgrave ved Ålborg. Skrivekridtet er fuldt af fossiler lige fra små muslinger, søpindsvin til hajer og den drabelige, men nu uddøde havøgle, mosasauren.

\section{Fiskeler}

Selv om Fiskeleret kun er få centimeter tykt, er det måske den mest berømte del af den danske undergrund. Midt i den hvide Stevns Klint ligger det mørke Fiskeler og markerer den 65 millioner år gamle grænse, hvor halvdelen af alle dyre- og plantearter uddøde. Forskere diskuterer, om den store masseuddøen skete på grund af omfattende vulkanudbrud, meteornedslag eller andre årsager, og Stevns Klint har en nøglerolle i denne diskussion.

\section{Mosdyrkalk/Bryozokalk}

Over hele Verden bruger geologer betegnelsen Danien om den tidsperiode, som følger efter den sidste store masseuddøen for 65 millioner år siden. Perioden er opkaldt efter Danmark, fordi kalken ved Stevns Klint og Faxe Kalkbrud stod som særligt gode

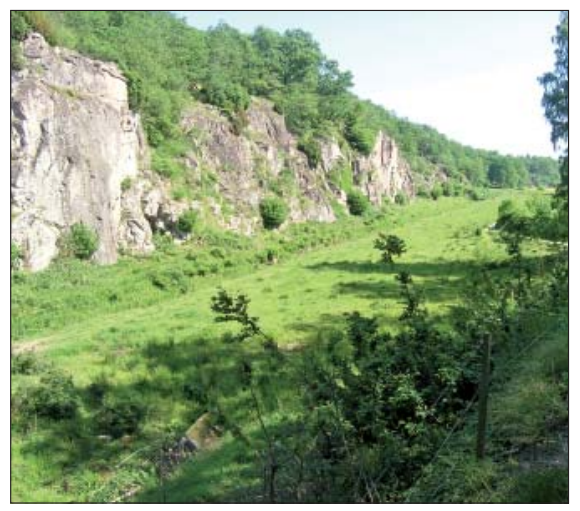

Sprcekkedale på Bornholm. (Foto: Henrik J. Granat)

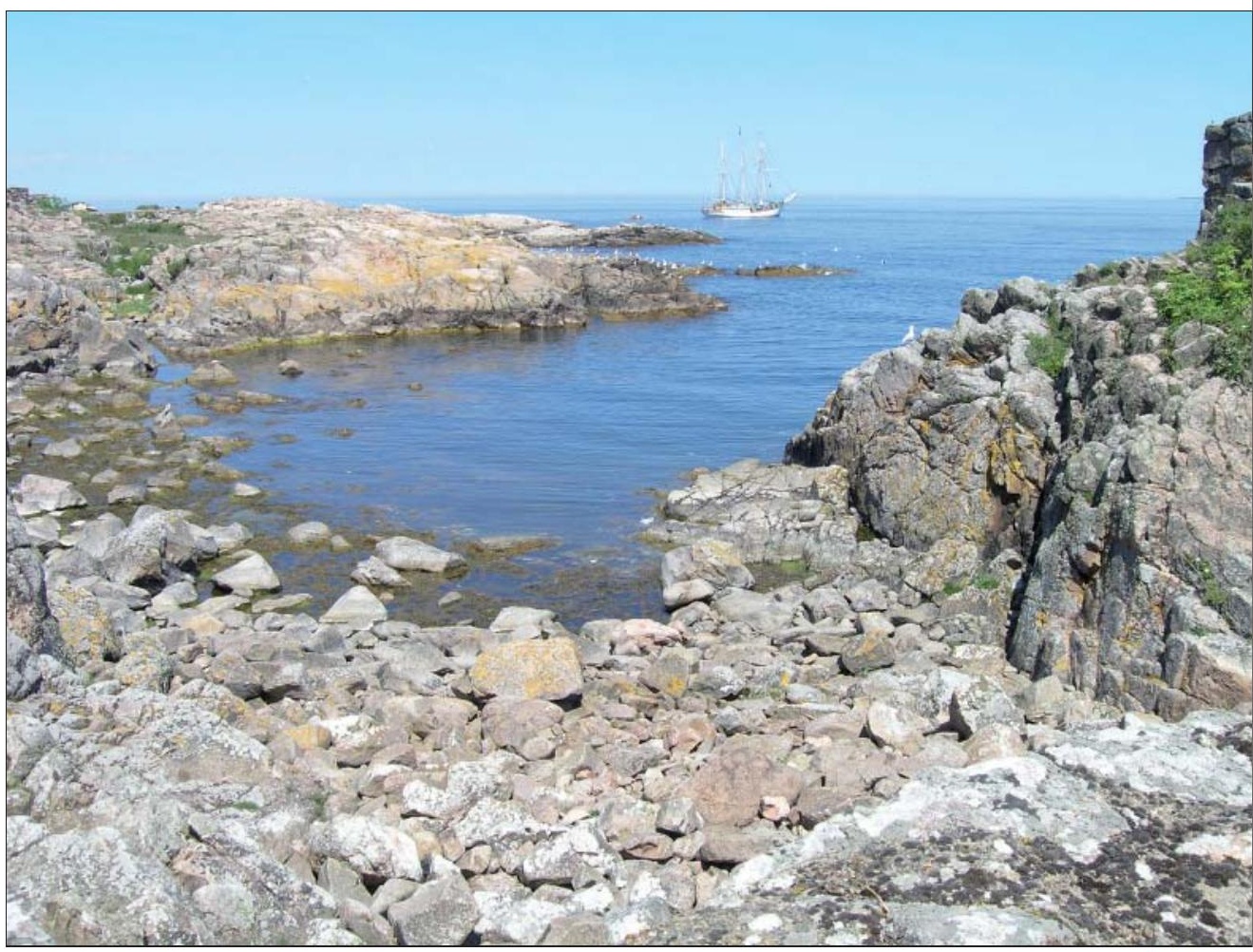

Grundfjeldet er blottet på Bornholm. (Foto: Henrik J. Granat)

steder at undersøge periodens lag. Kalken består mest af de små mosdyr/bryozoer, der voksede på havbunden i $10 \mathrm{~m}$ høje og 100 $\mathrm{m}$ lange banker. I kalken ses mange mørke lag af flint.

\section{Moler med askelag}

Hvert af de ca. 180 askelag, der kan ses som sorte striber i de smukke molersklinter i Limfjordsområdet, stammer fra et vulkanudbrud i det område mellem Grønland og Norge, hvor et nyt ocean - Atlanterhavet - var ved at opstå. Asken landede på havbunden i det hav, der dækkede området for ca. 55 millioner år siden. Selve moleret består af mikroskopiske alger og er kendt for sine fantastisk velbevarede fossiler, særligt fisk, insekter og fugle.

\section{Gram-ler}

Leret i Gram, brunkullet ved Fasterholt og sand og ler i kystklinter ved Lillebælt er eksempler på lag fra Neogen-tiden for 242,5 millioner år siden - lige før istiderne. I denne periode rykkede kystlinjen frem og tilbage over det danske område på grund af klimasvingninger og jordskorpebevægelser. Sand blev afsat i kystens laguner, ler på dybere havbund og brunkul i floders sumpede landområder. Gram-leret er kendt for mange flotte fossiler og fund af hvaler.

\section{Moræneler}

Moræneleret er den mest almindelige jordart i Danmark og ses i næsten alle danske klinter. Moræneler er ikke bare ler, men en usorteret blanding af ler, sand, grus og sten bragt hertil af istidernes gletschere. Nede under gletscherens bund blev denne kaotiske blanding afsat og smurt ud over landet. I Danmark er spor af fire istider, hver med flere gletscher-fremstød. Den sidste gletscher smeltede bort for ca. 15.000 år siden.

\section{Smeltevandssand/-grus}

I de mange store og grusgrave rundt omkring i landet får man et kig ned i de store mængder af smeltevandssand og -grus, der er efterladt af istidernes rivende smeltevandsfloder, der strømmede ud fra de smeltende gletschere. I smeltevandssandet og -gruset kan man se skrålag og andre strukturer, der viser, hvilken vej smeltevandet løb. Særligt i Vestjylland findes disse store sandog grusgrave.

\section{Opskudte lag}

Noget af Danmarks flotteste geologi er klinter med opskudte lag, bla. Møns Klint, Lønstrup Klint og molersklinterne på Fur og Mors. Her ser man oprindeligt vandrette lag, der nu er skubbet op og foldet rundt. Lagene er skudt op under og foran istidernes store gletschere og viser gletschernes enorme kraft.

\section{Forkastning/sprækkedal}

De bornholmske sprækkedale er svaghedszoner i grundfjeldet dannet ved bevægelser i jordskorpen og er en påmindelse om, at der neden under det danske istidslandskab findes en undergrund, hvori der kan ske bevægelser. Den største svaghedszone i den danske undergrund kaldes Sorgenfrei-Tornquist Zonen og løber fra Bornholm gennem Skåne og videre op gennem Kattegat. 
Stenene er udvalgt blandt de mest almindelige og genkendelige suppleret med nogle få helt særlige som rav og meteor. De fleste danske sten er transporteret hertil af isstrømme under istiderne og er udvalgt, så de fortæller om både istidshistorie og også om de mest almindelige bjergarter omkring os og har en aldersspredning, så de kan vise en tidsrejse i vores meget gamle forhistorie.

\section{Granit}

Granit er et let genkendeligt eksempel på en magmatisk sten, der er størknet dybt nede $i$ jordskorpen, når en smeltet stenmasse (et magma) langsomt afkøles og bliver til krystaller. Fordi afkølingen går så langsomt nede i dybet, har krystallerne tid til at vokse sig store, og i en granit kan man tydeligt se krystaller af røde, hvide og sorte mineraler, der er vokset tæt sammen som kantede puslespilsbrikker.

\section{Gnejs}

De tydelige lag af forskellige mineraler gør en gnejs til et let genkendeligt eksempel på en omdannet bjergart, også kaldet en metamorf bjergart. Selvom gnejsen ved første øjekast kan minde om en granit og er opbygget af de samme mineraler, afslører de tydelige lag af mineraler i forskellige farver, at stenen er omdannet under forhøjet tryk og temperatur, $\mathrm{fx}$ fra en bjergkædefoldning.

\section{3. Øjegnejs}

Øjegnejsen er en smuk og spektakuær sten med store røde eller lyserøde øje af feldspatkrystaller. Rundt om gnejsens "øjne" smyger sig lag af mørke mineraler.

\section{Basalt}

Den sorte basalt er med fraværet af synlige krystaller et let genkendeligt eksempel på en vulkansk sten. Stenen er dannet ved, at en flydende stenmasse (et magma) ved et vulkanudbrud er flydt ud som lava og er afkølet så hurtigt på jordens overflade, at krystallerne, der opbygger basalten, ikke har nået at vokse sig store.

\section{Rhombeporfyr}

Rhombeporfyren er en ledeblok, der er transporteret hertil med et isfremstød fra nord. Stenen stammer fra Oslo-området, hvor den findes som fast klippe. Rhombeporfyr findes næsten kun i Nordjylland og på Sjællands nordkyst og er et godt bevis på, hvor langt den Norske is nåede i sidste istid. Rhombeporfyr er også et eksempel på en porfyrisk lava, dvs. en lava, der først kom ud på over-

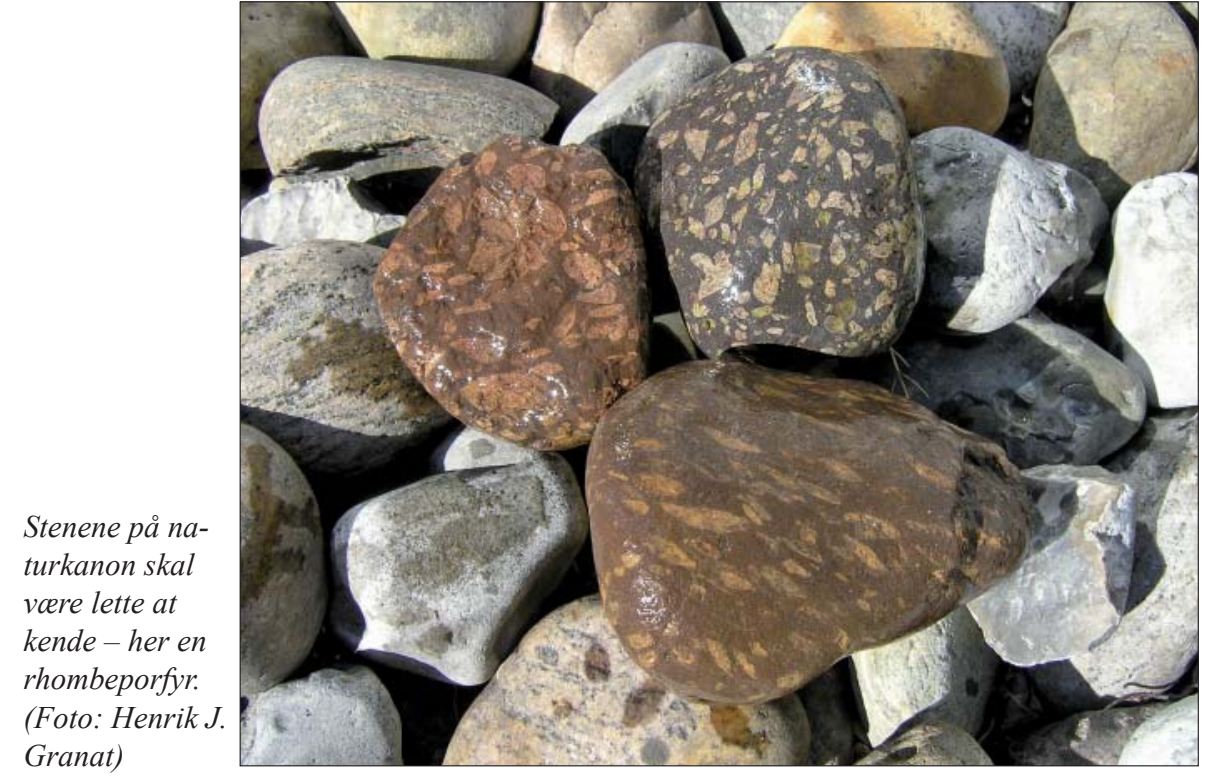

fladen, efter de første store krystaller var vokset i den flydende stenmasse.

\section{Kinnediabas}

Kinnediabas er en ledeblok bragt til Danmark med et isfremstød fra NØ. Kinnediabas kan ses som fast klippe ved Kinnekulle i Sverige. Kinnediabas er let at kende på sit blomkålslignende udseende og er almindelig på østdanske strande. Kinnediabasen er desuden et eksempel på en gangbjergart, hvor en smeltet stenmasse er løbet ind i en sprække nær jordoverfladen og størknet hurtigere end en granit, men langsommere end en basalt.

\section{Rød sandsten}

Røde sandsten er et godt eksempel på en aflejret bjergart. I stenen ses tydeligt hvert enkelt af de små, runde sandkorn, der engang var løse sandkorn i en ørken, men som nu er kittet sammen til en sten. Sandstenen ses som fast klippe på Bornholm, og rød sandsten er et let genkendeligt eksempel på en ledeblok, der er transporteret til det øvrige Danmark med en isstrøm, der er kommet fra øst gennem Østersøområdet.

\section{Ormerørssandsten}

Ormerørssandsten er et letgenkendeligt eksempel på en bjergart, der er aflejret $\mathrm{i}$ havet. Den består stærkt sammenkittede sandkorn, og den indeholder karakteristiske rørformede spor efter orm, der har gravet sig ned i den sandede havbund. Ormerørssandsten findes som fast klippe på Bornholm og er transporteret til det øvrige Danmark af isstrømme fra Østersøområdet.

\section{Kalksten}

Kalksten er et eksempel på en sten opbyg- get af skaller fra dyr. De enkelte kalkskaller kan være så små, at de ikke kan ses med det blotte øje, men i kalksten kan man også hyppigt finde store fossiler som fx blæksprutter, søpindsvin og muslinger. Kalkstenen kan kendes ved, at den bruser med syre.

\section{Flint}

Flint er et af de få eksempler, vi har på en kemisk dannet sten. Flint dannes nede i en kalkhavbund og består af kisel. Kislen stammer oprindeligt fra kiselalger og kiselsvampe, som bliver opløst, hvorefter flinten bliver dannet ved kemisk udfældning. Flint dannes ofte i gange fra gravende krebsdyr eller i skaller fra fx søpindsvin og har derfor ofte mærkelige former. Flint har haft stor kulturhistorisk betydning, særligt i stenalderen.

\section{Rav}

Rav er forstenet harpiks og er let at kende på sin farve, og fordi rav er blødere og lettere end andre sten. Det meste af det rav, der skyller op som små sten på de danske strande, menes at stamme fra Østersøområdet. Rav kan indeholde spor af tidligere tiders liv, fx frø og insekter. Rav har en lang og omfattende kulturhistorie, bl.a. som tidligt smykkemateriale.

\section{Meteorit}

Modsat alle andre danske sten er meteoritter ikke dannet på Jorden. Meteoritter er rester af himmellegemer, der har overlevet turen ind gennem Jordens atmosfære uden at brænde op. Meteoritter kan være svære at genkende, så selv om der sandsynligvis falder omkring tre meteoritter over Danmark om året, er der kun fundet ganske få. 